$$
\text { Pontificia } \mathrm{I}_{\text {niversigane }} \mathrm{C}_{\text {atglabica }}
$$

Sérgio Leão

Essays on Banking

Tese de Doutorado

Thesis presented to the Postgraduate Program in Economics of the Departamento de Economia,PUC-Rio as partial fulfillment of the requirements for the degree of Doutor em Economia.

Adviser:Prof. João Manoel Pinho de Mello Co-adviser:Prof.Claudio Abramovay Ferraz de Amaral

Rio de Janeiro

August 2011 


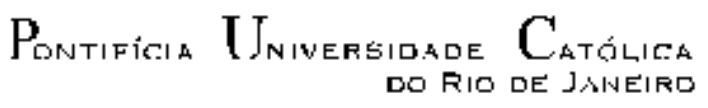

Sérgio Leão

\title{
Essays on Banking
}

Thesis presented to the Postgraduate Program in Economics of the Departamento de Economia, PUC-Rio as partial fulfillment of the requirements for the degree of Doutor em Economia.Approved by the following commission:

\author{
Prof. João Manoel Pinho de Mello \\ Adviser \\ Departamento de Economia - PUC-Rio \\ Prof. Claudio Abramovay Ferraz de Amaral \\ Co-Adviser \\ Departamento de Economia - PUC-Rio \\ Prof. Leonardo Rezende \\ Departamento de Economia - PUC-Rio \\ Prof. Rodrigo Reis Soares \\ Departamento de Economia - PUC-Rio \\ Prof. Armando Castelar Pinheiro \\ IBRE-FGV \\ Prof. Naércio Menezes Filho \\ USP/INSPER \\ Prof. Monica Herz \\ Coordinator of the Centro de Ciências Sociais - PUC-Rio
}

Rio de Janeiro, 25 de agosto de 2011 
All rights reserved

Sérgio Leão

Sérgio Leão graduated from the Universidade Federal de Goiás(Goiás,Brasil) in Civil Engineering in 1998.

Bibliographic data

Leão,Sérgio

Essays on Banking/ Sérgio Leão; adviser: João Manoel Pinho de Mello; co-adviser:Claudio Abramovay Ferraz de Amaral 2011.

90. : il. ; $30 \mathrm{~cm}$

Tese (Doutorado em Economia)-Pontifícia Universidade Católica do Rio de Janeiro, Rio de Janeiro, 2011.

Inclui bibliografia

1. Economia - Teses. 2. Bancos Públicos

Federais 3. Alinhamento Político 4. Favorecimento de Crédito 5. Contribuição de Campanha 6. Seguro Depósito I. Mello, João Manoel Pinho de. II. Ferraz, Claudio. III. Pontifícia Universidade Católica do Rio de Janeiro. Departamento de Economia. IV. Título. 


\section{Acknowledgements}

I will always be in debt to my beloved wife, Graziela Zucoloto, who has been a companion and indefatigable supporter over the last years.

I am very grateful to my advisors João Manoel de Mello and Claudio Ferraz for their guidance and support.

I would also like to thank Banco Central do Brasil for the financial support and access to data. The views expressed in this thesis are those of the author and do not necessarily reflect those of the Banco Central do Brasil. While those who helped me with the data are too numerous to mention, I thank Lucio Capelletto, Rogerio Rabelo and Roge Oliveira. I am also grateful for Edson Teixeira and Rodrigo Monteiro.

I am also obliged to the faculty and students of Puc-Rio. I thank Christiano Arrigoni, Marcos Castro, Thais Rodrigues, Waldyr Areosa, Marta Areosa, Mauricio Fernandes, Bruno Otoni, Joana Monteiro, Isabelle Agier, Marcelo Nuno and all fellows of Favelinha. From administrative staff, I am very grateful to Graça for the constant help. 


\section{Abstract}

Leão, Sérgio; Mello, João Manoel Pinho de (Advisor); Ferraz, Claudio (Co-advisor). Essays on Banking. Rio de Janeiro, 2011. 90p. Tese de Doutorado - Departamento de Economia, Pontifícia Universidade Católica do Rio de Janeiro.

This thesis is a collection of three empirical essays on banking using Brazilian data. Chapter 1 provides evidence that cities ruled by a mayor from the presidential coalition's party receive significantly more credit from public federally owned banks. Using a unique longitudinal database that matches branch-level credit information with election outcomes over the period 1997-2008, I explore the within-municipality variation in political alignment to estimate the impact of alignment on the amount of credit. I find that public federal banks increase their lending $10 \%$ more in aligned cities. In response, private banks contract credit, but the net effect is an increase in aggregate credit to aligned cities, raising the issue of a misallocation of capital across cities. I also use another unique and more comprehensive credit database, available only since 2004, and apply a regression discontinuity design in close electoral races to address possible identification concerns. In contrast with the received literature, I find that the results are not driven by earmarked lending, but by non-earmarked operations. Chapter 2 focuses the analysis on firms that donate to electoral campaigns in order to test for the hypothesis of favored lending as a reward mechanism for campaign giving. I combine data from firm level campaign contributions with credit information and explore within-firm variation in order to test whether donating to aligned parties results in a better access to credit from public federal banks. Results indicate that campaign contributors to aligned parties have a higher lending share from public federal banks and borrow $20 \%$ more than firms that donate to nonaligned parties. In Chapter 3 I take advantage of the introduction of a voluntary deposit insurance program to address several important questions concerning bank runs, market liquidity and funding liquidity. I first document a depositors' run on small and medium banks in Brazil after the worsening of the global financial crisis. Second, I find that the bank run was led mainly by institutional investors. Third, I show that, in response to the weakening position on the liability side, banks responded by liquidating their credit position on the asset side of the balance sheet. Fourth, I find evidence 
that the introduction of a new voluntary insurance instrument called DPGE (Time Deposits with Special Insurance) seemed to have helped stabilize banks' positions. Under DPGE, Certificates of Deposit (CD) are insured up to R $\$ 20$ million, while standard non-DPGE other time deposits are secured up to R\$ 60 thousand. Fifth, I show that banks whose assets were more illiquid selected themselves into expensive DPGE (issuers have to pay monthly premium of more than six times the value charged on conventionally insured deposits). Thus, providing funding liquidity was more important for banks that were more affected by market liquidity (having less liquid assets). An investigation of the determinants of issuing DPGE shows that: 1) banks that relied more on credit assignments before the crisis are more likely to issue under the new insurance scheme; 2) banks with higher credit-to-assets ratios are also more likely to issue under the new scheme, although the results on credit-to-assets are a little less precise. These results are important for several reasons. First, they are the first empirical results to document the relationship between market and funding liquidity. In particular, self-selecting into DPGE allows us to see that banks with more illiquid assets need more funding liquidity in the midst of a crisis. Second, the fact of the voluntary nature of the program is interesting per se. By providing voluntary, albeit expensive, insurance, banks may self-select only when they have little option (because of asset-side market illiquidity). Although I do not perform a full welfare analysis, this suggests that mandatory insurance may be sub-optimal for two reasons. First, banks that do not need it may be paying excessive premiums. Second, mandatory insurance may induce more expost risk taking than otherwise needed if the moral hazard on insured deposits is empirically relevant.

\section{Keywords}

Public Federal Banks; Political Alignment; Misallocation; Favored Lending; Campaign Contribution; Deposit Insurance; Market Liquidity; Funding Liquidity 


\section{Resumo}

Leão, Sérgio; Mello, João Manoel Pinho de (Orientador); Ferraz, Claudio (Co-orientador). Ensaios em Economia Bancária. Rio de Janeiro, 2011. 90p. Tese de Doutorado Departamento de Economia, Pontifícia Universidade Católica do Rio de Janeiro.

Esta tese é uma coleção de três ensaios empíricos em economia bancária no Brasil. $\mathrm{O}$ capítulo 1 mostra evidências que cidades governadas por prefeitos da base aliada do governo federal recebem mais crédito de bancos públicos federais. Utilizando uma base de dados longitudinal única que cruza informações de crédito em nível municipal com resultados eleitorais no período 1997-2008, eu exploro variações no alinhamento político de cada município ao longo do tempo para estimar seu impacto no montante de crédito. Como resultado, observo que os bancos públicos federais aumentam seus empréstimos em $10 \%$ a mais em cidades alinhadas. Em resposta, os bancos privados restringem sua expansão de crédito nessas localidades, embora o efeito líquido seja de um aumento no crédito agregado para cidades alinhadas, deixando a questão de uma provável má alocação de capital entre cidades. Eu também utilizo outra base de dados de crédito única e ainda mais abrangente, disponível somente a partir de 2004, e emprego a metodologia de regressão com discontinuidade em disputas eleitorais apertadas para avaliar possíveis problemas de identificação. Em contraste com a literatura, eu observo que os resultados não são conduzidos por empréstimos direcionados, mas por operações de crédito livre. $\mathrm{O}$ capítulo 2 analisa firmas que contribuem para campanhas eleitorais de modo a testar a hipótese de favorecimento de crédito como retribuição a contribuição de campanha. Combinando dados de contribuição de campanha e informações de crédito ao nível da firma, eu exploro variações em uma mesma firma ao longo do tempo para testar se aquelas que contribuem para partidos da base aliada do governo federal recebem mais crédito de bancos públicos federais. Os resultados indicam que contribuintes de campanha de partidos da base aliada têm maior proporção de seu crédito oriundo de bancos públicos federais e tomam de uma maneira geral $20 \%$ a mais de crédito que firmas que contribuem para outros partidos. No capítulo 3, eu aproveito da introdução de uma nova forma de seguro depósito voluntário, conhecido por DPGE (Depósito a Prazo com Garantias Especiais), para avaliar questões relevantes relativas a corrida bancária, liquidez de mercado (market liquidity) e liquidez na captação (funding liquidity). Primeiramente, documento uma corrida de depositantes a bancos pequenos e médios no Brasil após o agravamento da crise financeira global de 2008. A seguir, observo que esta corrida bancária foi 
impulsionada primordialmente por investidores institucionais. Em seguida, demonstro que, em resposta ao enfraquecimento da posição no seu passivo, os bancos reduziram seu ativo liquidando suas posições de crédito. Em quarto lugar, encontro evidências de que a introdução do DPGE ajudou a estabilizar as captações bancárias. Com este novo instrumento, os certificados de depósito (CD) passaram a ser segurados em até R\$ 20 milhões, enquanto os demais eram segurados em até R\$ 60 mil. Por fim, demonstro que bancos com menor liquidez nos ativos foram aqueles que escolheram emitir DPGE, apesar de seu elevado custo (emissores devem pagar prêmio mensal de mais de seis vezes o valor cobrado em depósitos segurados convencionais). Portanto, restaurar a liquidez pelo lado do passivo (funding liquidity) foi mais importante a bancos mais afetados pela liquidez de mercado (market liquidity), ou seja, para aqueles com menos ativos líquidos. Uma investigação dos determinantes da emissão de DPGE mostra que: 1) bancos mais dependentes de cessão de carteira de crédito antes da crise estão mais propensos a emitir no novo esquema de depósito segurado; e 2) bancos com proporção mais elevada de crédito em relação ao ativo estão mais propensos a emitir sob o novo esquema, embora os resultados sejam menos precisos. Tais resultados são importantes por diversas razões. Primeiramente, estão entre os primeiros resultados empíricos a documentar a relação entre liquidez de mercado (market liquidity) e liquidez na captação (funding liquidity). Em particular, auto-seleção no DPGE permite observar que bancos com mais ativos não líquidos dependem mais de funding liquidity no meio de uma crise. Além disto, a natureza voluntária do programa é interessante per se. Provendo seguro voluntário, embora custoso, os bancos podem optar pelo seguro somente quando não dispõe de outra opção de captação, ou devido à falta de liquidez de mercado dos ativos. Apesar de não realizar uma análise completa de bem estar, o estudo realizado sugere que impor seguros obrigatórios a todos participantes nos momentos de crise pode ser sub-ótimo por duas razões: pelo fato de os bancos que não necessitam serem obrigados a pagar prêmios excessivos, e porque seguros obrigatórios podem induzir a mais risco ex post caso o risco moral em depósitos segurados seja empiricamente relevante.

\section{Palavras-chave}

Bancos Públicos Federais; Alinhamento Político; Má Alocação de Recursos; Favorecimento de Crédito; Contribuição de Campanha; Seguro Depósito; Liquidez de Mercado; Liquidez na Captação 


\section{Contents}

1 The Effect of Political Alignment on Public Federal Bank Lending 12

1.1. Introduction 12

1.2. Background and Data 17

1.2.1. Institutional Environment 17

$\begin{array}{ll}\text { 1.2.2. Data } & 18\end{array}$

1.3. Empirical Strategy 20

1.4. Results 24

1.4.1. Do aligned municipalities receive more credit from public federal banks? 24

1.4.2. Does political alignment distort total credit allocation

across cities? 26

1.4.3. What drives credit redistribution of public federal banks? 26

1.5. Robustness and Validity Tests 28

1.5.1. Robustness Checks on Diff-in-Diff Estimations 28

1.5.2. Validity Tests for Regression Discontinuity Design 28

1.6. Conclusion 29

2 Campaign Contribution and Access to Credit 41

2.1. Introduction 41

2.2. Data 44

2.2.1. Data Sources 44

2.2.2. Descriptive Statistics 45

2.3. Empirical Analysis 47

2.3.1. Do campaign contributors to aligned parties have preferential access to banking finance? $\quad 47$

2.3.2. Do campaign contributors to aligned parties have preferential access to public federal bank lending? 52 
2.4. Extensions 53

2.5. Conclusion 54

2.6. Appendix 56

3 Market Liquidity and Funding Liquidity in a Bank Run:The Brazilian DPGE Experiment 63

3.1. Introduction 63

3.2. The Time Deposits with Special Insurance - DPGE 65

3.3. Data and Descriptive Statistics 66

3.3.1. Data Sources 66

3.3.2. Descriptive Statistics 66

3.4. Empirical Analysis 68

3.4.1. Determinants of the Bank Run 68

3.4.2. Determinants of Issuing DPGE 69

3.4.3. Determinants of the Amount of DPGE issuance 70

3.4.4. The role of DPGE issuance on deposit recovery 72

3.5. Conclusion 72

$\begin{array}{ll}4 \text { References } & 87\end{array}$ 


\section{List of Figures}

1.1 Effect of Political Alignment on State-Owned Bank Lending: Evidence from Close Electoral Races $\quad 30$

1.2 Effect of Political Alignment on State-Owned Bank Lending by Type of Credit 31

1.3 Effect of Political Alignment on State-Owned Bank Lending by Type of Borrower 32 1.4 Validity Checks: Testing for Discontinuity of Public Federal Bank Lending in 2004, municipal characteristics and the Effect for Private Banks after the Election (Placebo)

3.1 Evolution of Total Time Deposits ( $R \$$ Billion) of Small and Medium banks

. Right graph shows the evolution of deposits dividing small and medium banks in DPGE issuers and non-Issuers DPGE issuers and non-issuers

3.2 Evolution of Time Deposits by group of banks 75

3.3 Evolution of Time Deposits held by Institutional Investors 75

3.4 Evolution of Time Deposits held by individuals (log) 76

3.5 Evolution of Time Deposits held by Non-Financial Firms 76

3.6 Evolution of Time Deposits held by Financial Institutions 77

3.7 Evolution of Credit-to-Asset Ratio 77

3.8 Evolution of Credit Assignment 78

3.9 Evolution of Time Deposits Ratio 78

3.10 Evolution of Foreign Deposits Ratio 79 